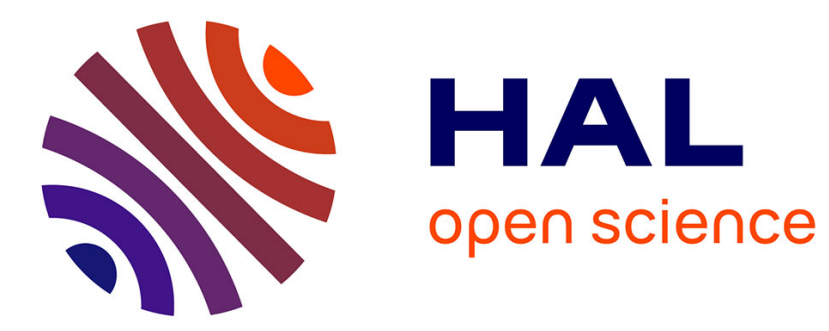

\title{
International publication trends in dry eye disease research: A bibliometric analysis
}

Christophe Boudry, Christophe Baudouin, Frédéric Mouriaux

\section{To cite this version:}

Christophe Boudry, Christophe Baudouin, Frédéric Mouriaux. International publication trends in dry eye disease research: A bibliometric analysis. The Ocular Surface, 2017, 10.1016/j.jtos.2017.10.002 . hal-01658300

\section{HAL Id: hal-01658300 https://hal.science/hal-01658300}

Submitted on 7 Dec 2017

HAL is a multi-disciplinary open access archive for the deposit and dissemination of scientific research documents, whether they are published or not. The documents may come from teaching and research institutions in France or abroad, or from public or private research centers.
L'archive ouverte pluridisciplinaire HAL, est destinée au dépôt et à la diffusion de documents scientifiques de niveau recherche, publiés ou non, émanant des établissements d'enseignement et de recherche français ou étrangers, des laboratoires publics ou privés. 


\section{Accepted Manuscript}

¿ocularSurface

International publication trends in dry eye disease research: A bibliometric analysis

Christophe Boudry, C. Baudouin, Fréderic Mouriaux

PII:

S1542-0124(17)30129-5

DOI:

10.1016/j.jtos.2017.10.002

Reference: JTOS 263

To appear in: Ocular Surface

Received Date: 17 May 2017

Revised Date: 27 September 2017

Accepted Date: 8 October 2017

Please cite this article as: Boudry C, Baudouin C, Mouriaux Fré, International publication trends in dry eye disease research: A bibliometric analysis, Ocular Surface (2017), doi: 10.1016/j.jtos.2017.10.002.

This is a PDF file of an unedited manuscript that has been accepted for publication. As a service to our customers we are providing this early version of the manuscript. The manuscript will undergo copyediting, typesetting, and review of the resulting proof before it is published in its final form. Please note that during the production process errors may be discovered which could affect the content, and all legal disclaimers that apply to the journal pertain. 


\section{ACCEPTED MANUSCRIPT}

International publication trends in dry eye disease research: a bibliometric analysis

\section{Authors}

Christophe Boudry, PhD ${ }^{1,2,3}$, C. Baudouin, MD, PhD ${ }^{4,5}$, Fréderic Mouriaux, MD, PhD ${ }^{6,7}$,

\section{Affiliations}

${ }^{1}$ Normandie Univ, UNICAEN, Média Normandie. Caen, France

${ }^{2}$ URFIST, Ecole Nationale des Chartes, PSL Research University. Paris, France

${ }^{3}$ Laboratoire "Dispositifs d'Information et de Communication à l'Ère Numérique",

EA7339, Conservatoire National des Arts et Métiers, Paris, France

${ }^{4}$ Department of Ophthalmology III, Quinze-Vingts National Ophthalmology Hospital, Paris, France;

${ }^{5}$ INSERM, U968, Paris, F-75012, France; Sorbonne Universités, UPMC University Paris 06, UMR S

968, Institut de la Vision, Paris, F-75012, France; CNRS, UMR_7210, Paris, F-75012, France;

${ }^{6}$ Service d'Ophtalmologie, CHU Rennes, Université Rennes 1, Rennes, France

${ }^{7}$ Faculté de Médecine, Rennes, France

\section{Corresponding author}

Christophe Boudry

Media Normandie, Université de Caen Normandie

Esplanade de la Paix

CS 14032, 14032 Caen Cedex 5, France

christophe.boudry@enc-sorbonne.fr 


\title{
Abstract
}

Purpose: To perform a bibliometric analysis in the field of dry eye disease (DED) research to characterize the current international status of DED research and to identify the most effective actors (journals, countries, authors) involved in this field

Methods: Scientometric methods were used to evaluate global scientific production and development trends in DED research using the Web of Science Core Collection

Results: The growth of the literature related to DED averaged $12.18 \%$ over the last 10 years. A total of 5522 original and review articles, published in 821 different journals, were identified. The USA was the most productive country with $34.53 \%$ of the overall articles studied and $46.10 \%$ of the overall citations. The Ocular Surface published a very high percentage of articles related to DED relative to the total number of articles published (31.87\%). The most productive institutions and the most frequently cited articles were from the USA and Japan. A network visualization map for country collaboration revealed that most European countries developed most of their collaborations with countries belonging to their own continent, which was not the case for the USA or Japan. A total of 41,956 KeyWords Plus were found with an average of $7.6(S D=3.15)$ KeyWords Plus per article

Conclusions: This study provides a broad view of the current status and trends in DED research and may help clinicians, researchers and policy makers better understand this research field and predict its dynamic directions.

\section{Keywords}

Dry eye disease, Ophthalmology, Science publishing, Journals, Bibliometrics

\author{
Abbreviations \\ DED Dry eye disease \\ JCR Journal Citation Reports \\ WoS Web of Science
}




\section{Introduction}

The term "dry eye disease" (DED), often synonymous with "dry eye syndrome," "keratoconjunctivitis sicca" and "dysfunctional lacrimal functional unit," is a multifactorial disease of the tears and ocular surface that results in symptoms of discomfort, visual disturbance, and tear film instability with potential damage to the ocular surface [1]. Generally, DED patients may experience ocular discomfort, including but not limited to pain, burning sensation, foreign body sensation, grittiness and tearing. Others may complain of dryness, ocular fatigue, and sometimes redness. DED is a common condition across populations because the prevalence of DED has been described up to $34 \%$ $[2,3]$.

A bibliometric method is the application of quantitative and qualitative analysis to the publication of journals and articles and their accompanying citation counts over time [4,5]. It can characterize the current status of research fields by measuring scientific output of an institution or country and has played a great role in the past in governing policymaking [6] and better understanding scientific fields [7]. It also enables researchers to determine the range of research topics and identify new topics, and assists them in planning their research direction and predicting research trends [8]. A number of bibliometric studies have investigated the publishing trends in ophthalmology concerning the research output of specific countries or areas $[9,10]$, subspecialties $[11-13]$ or the production of a selection of ophthalmology journals [14]. To the best of our knowledge, there are no bibliometric analyses that have explored research related to DED. This study used bibliometric tools to analyze DED articles retrieved on the Web of Science (Thomson Reuters Company) database and provides a retrospective and current view of the mainstream research on DED throughout the world.

\section{Material and Methods}

The search for papers to be included in this study was carried out on 15 February 2017, using the database Science Citation Index Expanded (SCI-EXPANDED) via the Web of Science Core Collection (WoS) provided by Thomson Reuters (Philadelphia, PA, USA). The database was searched using the term "dry eye" in terms of "Topic" (title, abstract, author's keywords, and WoS-assigned keywords called KeyWords Plus) in order to retrieve all articles where the expression "dry eye" appeared, but also the expressions "dry eye disease" or "dry eye syndrome" and all possible variants (e.g., dry eye diseases). Only articles and reviews were included as document types (non-article-type documents such as meeting abstracts, editorial materials, proceedings papers, letters, book chapters, news items, corrections, and notes were excluded). Journal articles and reviews were used for the analysis 
because they accounted for the majority of document types that also included complete research ideas and results [15].

Data were downloaded from WoS in "Full record and cited references" and "Comma Separated Values" (CSV) formats. HISTCITE 12.3.17 (Thomson Reuters, Philadelphia, PA, USA) and Microsoft Excel 2013 (Microsoft, Redmond, WA, USA) software tools were used to analyze the data. Author's keywords and KeyWords Plus were analyzed in Microsoft Excel from raw data downloaded from WoS (CSV format). VOSviewer (Leiden University, Leiden, Netherlands) was used to generate the knowledge maps of countries related to DED research. Citation counts reflect all the papers obtained on 15 February 2017 when the WoS database search process for this study was conducted. The 2015 Journal Citation Reports (JCR) (Thomson Reuters, Philadelphia, PA, USA) was used to determine the Impact Factor (IF) and rank the journal in the "Ophthalmology" category of the JCR.

The average yearly growth rate of the literature related to DED was calculated as the mean percentage of the annual growth rate using the equation: (Annual Growth Rate $=$ Current Year Total Number of Articles - Previous Year Total Number of Articles)/Previous Year Total Number of Articles [16]. The average yearly growth rate was also calculated for the whole WoS database. Using Excel software, the total number of articles related to DED per year was fitted to a linear equation as well as an exponential curve for our search strategy.

Countries, institutions, authors, journals, languages of publication, subject categories and most-cited articles were also examined. Institutions were determined using the "Organizations - Enhanced" field. Articles originating from England, Scotland, Northern Ireland and Wales were reclassified as being from the United Kingdom (UK). To locate the most popular research topics and their trends, the author's keywords and KeyWords Plus was also investigated. KeyWords Plus supplies additional search terms generated by an automatic computer algorithm, extracted from titles of articles cited by authors in their bibliographies and footnotes, and substantially increase title-word and authorkeyword indexing [17]. KeyWords Plus may be present for articles that have no author keywords or may include important terms not listed among the title, abstract or author keywords. The frequency of KeyWords Plus was calculated.

\section{Results}

\section{Overall publication trends}

The search in the WoS database resulted in a total of 5522 articles cited 104,234 times (mean 18.88 citations per article). The first article dealing with dry eye disease (DED) appeared in 1952 and the 
number of articles produced overall grew to 606 in 2016. Using the cumulative number of publications, we calculated the linear adjustment and the exponential adjustment and found $\mathrm{y}=$ $73.539 x-145613$ with $r^{2}=0.5905$, and $y=6^{-137 *} e^{0,16 x}$ with $r^{2}=0.9842$, respectively (Figure 1 ). We also calculated that the average growth rate of the literature related to DED was $12.18 \%$ and $15.75 \%$ over the last 10 years and 15 years, respectively. We calculated that the average growth rate for the whole WoS database was $3.97 \%$ and $3.78 \%$ for the same periods. The difference in growth rates between the growth rate of eye diseases and all scientific production in the WoS database is equal to $8.21(12.18$ - 3.97.) and $11.97(15.75-3.78)$ over the last 10 and 20 years, respectively.

\section{Countries and institutions}

Seventy-seven countries were identified and analysis was performed on 5522 (97.14\%) articles; 158 (2.86\%) articles were recorded without author information. The USA accounted for the largest number of articles published (Table 1). Interestingly, six countries (USA, Japan, People's Republic of China, France, Canada and Brazil) had a higher percentage of citations as compared to the percentage of articles they published, showing that the articles of these countries are more frequently cited. To further develop the country study, a network visualization map for country collaboration is shown in Figure 2: This map shows that most European countries developed most of their collaborations with countries belonging to their own continent. In contrast, the USA collaborates more specifically with the People's Republic of China and/or Japan. Some of the most productive countries such as South Korea and Brazil have developed fewer collaborations with other countries.

We also analyzed the main institutions implicated in the DED publication. Table 2 shows the output of the top 15 institutions for the 5522 articles studied. It was likewise significant that the USA also had the largest number of articles and citations, indicating that institutions in the USA played a crucial role in DED research. Twelve institutions have a higher percentage of citations as compared to the percentage of articles they published: for example, Harvard University contributed $5.43 \%$ of the articles related to DED but received $9.19 \%$ of the overall citations (nearly twice the expected value), showing that articles from this institution have a great scientific impact.

\section{Authors and most-cited articles}

The total number of authors retrieved in the 5522 articles related to DED was 27,566, an average of 4.99 authors per article. The number of different individual authors was 13,885 . The great majority of authors ( $n=9934 ; 71.55 \%)$ wrote only one article, 1846 (13.29\%) wrote two, whereas 2105 (15.16\%) wrote three or more. Table 3 presents the 15 most productive authors in DED research. This small 
group of 15 authors ( $0.11 \%$ of all authors) contributed a total of 1273 articles ( $23.05 \%$ of the overall articles) who were cited 46,126 times (44.25\% of the overall citations).

Among these 5522 articles, the three most frequently cited articles were: "The importance of the omega-6/omega-3 fatty acid ratio in cardiovascular disease and other chronic diseases" by Simopoulos AP published in 2008 in Experimental Biology and Medicine (794 citations, 88.22 citations per year), "The definition and classification of dry eye disease: Report of the Definition and Classification Subcommittee of the International Dry Eye WorkShop (2007)" by Lemp MA, Baudouin C, Baum J, Dogru M, Foulks GN, et al. published in 2007 in The Ocular Surface (669 citations, 66.9 citations per year) and "Reliability and validity of the ocular surface disease index" by Schiffman RM, Christianson MD, Jacobsen G, Hirsch JD, Reis BL, published in 2000 in Archives of Ophthalmology (668 citations, 39.29 citations per year). See Supplementary data for the following 17 most-cited articles.

\section{Publication patterns}

A total of 5522 articles related to DED were published in a wide range of 821 journals. Out of these 821 journals, 467 (54.74\%) published only one article. Only 60 (7.31\%) journals published more than ten articles. Table 4 lists the 20 journals with the greatest number of papers published on DED. These top 20 journals published 2947 articles, corresponding to $53.37 \%$ of the total articles on DED. These 2947 articles received 68,039 citations that correspond to $65.28 \%$ of the overall citations. For a more precise view of the publication trends over the last 9 years, we decided to divide the last 9 years into three periods (2008-2010, 2011-2013, 2014-2016): Some journals published a growing number of articles related to DED over these last 9 years while others published fewer articles (i.e., JAMA Ophthalmology).

The study of the top 20 most-cited articles showed that five were published in journals not belonging to the JCR "Ophthalmology" category (Experimental Biology and Medicine, Biomedicine \& Pharmacotherapy, The New England Journal of Medicine, Biomedicine \& Pharmacotherapy and the International Journal of Pharmaceutics). The Ocular Surface published a very high percentage of articles related to DED relative to the total number of articles published (31.87\%), as compared to other journals. JAMA Ophthalmology and Ophthalmology have the highest number of citations per article considering DED research.

Thirteen languages of publication were identified in the 5522 articles retrieved. The three predominant languages were English ( $n=5250 ; 95.07 \%)$, German $(n=140 ; 2.54 \%)$ and French $(n=78$; 1.41\%). All other languages (Portuguese Polish, Slovene, Spanish, Italian, Serbian, Turkish, Hungarian, Korean and Russian) amounted to less than $1 \%$. 


\section{Subject categories and distribution of KeyWords Plus}

Based on the JCR categories, the DED publication output data was distributed into subject categories. Quite logically the most frequent category was by far "Ophthalmology" ( $n=3892 ; 70.48 \%)$ followed by "Pharmacology \& Pharmacy" ( $n=312 ; 5.65 \%)$ and "Surgery" ( $n=258 ; 4.67 \%)$ (see Supplementary data for the following seven categories).

The number of different author's keywords and KeyWords Plus (KeyWords Plus supplies additional search terms extracted from titles of articles cited by authors in their bibliographies and footnotes) totaled 6827 and 7690, respectively. A total of 17,784 author's keywords were found in 3505 articles (2017 articles did not have author's keywords) and the average number of keywords was 5.1 (SD= 1.82 per article). KeyWords Plus amounted to 41,956 and were found in 5522 articles; the average number of KeyWords Plus was $7.6(S D=3.15)$ per article. Because 2017 (36.52\%) articles did not have author's keywords and to avoid bias in the analysis, we decided to proceed with the frequency analysis using only the KeyWords Plus, which were found in $100 \%$ of the articles studied. Table 5 lists the top 20 KeyWords Plus retrieved.

\section{Discussion}

This study sought to provide a detailed evaluation of the published literature on DED using the Science Citation Index Expanded (SCI-EXPANDED) database via the Web of Science Core Collection (WoS). To the best of our knowledge, such a bibliometric analysis related to DED has never been performed previously, and a network visualization map for country collaboration has never been applied to the field of ophthalmology. The WoS database used in this study, contrary to PubMed, which is also used for bibliometric analysis as we have done in the past [11,12], can quantify citations of articles and provide access to qualitative evaluation. Nevertheless, contrary to the WoS database, PubMed has the advantage of proposing a controlled vocabulary thesaurus: "Medical Subject Headings" (MeSH) (http://www.nlm.nih.gov/pubs/factsheets/mesh.html), which helps during the search process and helps map research fields in bibliometric analysis by analyzing the MeSH terms $[11,18,19]$. However, there are limitations in the present study: the counting of citations over time advantages older over newer articles, which can introduce bias in the interpretation of this parameter. Articles in other languages than English may not be included in the database and analyzed: the WoS database has been criticized for its heavy bias in favor of English-language journals $[4,20]$. Even else we tried to adjust our query in order to extract all articles dealing with DED in a significant way, some relevant articles may have been missed and some irrelevant may have been included (due to the large number of articles retrieved a manual analysis to control the relevance of articles was impossible). 
With an average growth of $15.75 \%$ over the last 10 years, the growth of DED publications is higher than for the whole WoS database (3.78\%) and is exponential. This indicates great interest in DED on the part of the scientific community, "an attractive topic in science" according to Michon et al. [21] with its high publication rate [22]. This interest may be due to the high prevalence of DED [2,3] and the development of strategies for diagnosis and treatment [23]. The USA is by far the most productive country and is responsible for the greatest of number of citations. Interestingly, Japan was the second most productive country, a rank this country has never reached in other bibliometric analyses in the field of ophthalmology $[11,12,24]$.

Interestingly, a very small proportion of the authors was responsible for nearly a quarter of the articles related to DED and for nearly a half of the total article citations related to DED. The same phenomenon was found for publication patterns that showed a high concentration of articles and citations in a few journals, which is consistent with former studies $[16,25,26]$. The Ocular Surface is the journal that by far publishes the highest percentage of articles related to DED (31.87\%) and should be considered as the most specialized journal in DED. Among the 20 most productive journals, it is interesting to note that the mega-journal Plos One is the only journal belonging to the "Multidisciplinary Sciences" JCR category, all the other journals logically belonging to the "ophthalmology" JCR category, confirming the important role Plos One plays in the dissemination of information in life sciences, despite accepting submissions from all areas of science [27].

The analysis of keywords provides details of the articles' subject and offers additional information on research trends [28], and they have proved to be important in monitoring the development of science [29]. As in former studies [29,30], we initially decided to analyze author's keywords and KeyWords Plus. In agreement with previous observations [28], our search yielded many more KeyWords Plus than author's keywords, and contrary to KeyWords Plus, we found that author's keywords were present only in $64.47 \%$ of articles, very close to the value found in [31]. The absence of author's keywords in some articles can be explained by the fact that some journals (e.g., British Journal of Ophthalmology) do not require authors to provide keywords during the submission process, whereas some do (e.g., The Ocular Surface). It has also been proven that the "lack of standardization among author's keywords can greatly hamper the analysis since the use of synonymous terms, spelling variations, abbreviations, and more or less specific terms made the exact interpretation of the author's intended meaning difficult" [32]. Moreover, "KeyWords Plus are as effective as Author Keywords in terms of bibliometric analyses investigating the knowledge structure of scientific fields, but it is less comprehensive in representing an article's content" because KeyWords Plus are more broadly descriptive ([28]. Consequently, we decided to perform a frequency analysis only for KeyWords Plus. This analysis of the top 20 KeyWords Plus maps the DED research 
field. Most of the synonyms of "dry eye" are found in this list ("dry eye disease", "dry eye syndrome" and "keratoconjunctivitis sicca"), showing that using "dry eye" in terms of "Topic" during the search process in the WoS database efficiently retrieved articles related to DED. One must note that the search for DED in the PubMed database would have been different because it would have used the MeSH term "Dry eye syndrome"; "Dry eye disease" is not the term used in the MeSH vocabulary and its use in no way leads to the discovery of synonyms allowing an efficient bibliographic search [33].

\section{Conclusions}

These results may be helpful for all those involved in worldwide DED research. Indeed, this study can help clinicians and researchers better understand DED research worldwide and help them, for example, choose appropriate journals for publication and collaborations. Fellows choosing an institution for advanced work may also be interested in such an analysis. Journals can determine where they stand in relation to other journals in publishing articles related to DED. Governments and policy makers can also ascertain the most effective countries and institutions in the world in this field, and this analysis may assist them to apprehend and predict the dynamic directions of DED research and to target resources so that further developments can be encouraged, supported and monitored. 


\section{References}

[1] The definition and classification of dry eye disease: report of the Definition and Classification Subcommittee of the International Dry Eye WorkShop (2007). Ocul Surf 2007;5:75-92.

[2] Terry MA. Dry eye in the elderly. Drugs Aging 2001;18:101-7.

[3] Gayton JL. Etiology, prevalence, and treatment of dry eye disease. Clin Ophthalmol 2009;3:405-12.

[4] Agarwal A, Durairajanayagam D, Tatagari S, Esteves SC, Harlev A, Henkel R, et al. Bibliometrics: tracking research impact by selecting the appropriate metrics. Asian J Androl 2016;18:296-309. doi:10.4103/1008-682X.171582.

[5] Glänzel W, Magyar Tudományos Akadémia, Kutatásszervezési Intézet. Bibliometrics as a research field: a course on theory and application of bibliometric indicators. Budapest: Magyar Tudományos Akadémia, Kutatásszervezési Intézet; 2003.

[6] King DA. The scientific impact of nations. Nature 2004;430:311-6. doi:10.1038/430311a.

[7] Bar-Ilan J. Informetrics at the beginning of the 21st century-A review. Journal of Informetrics 2008;2:1-52. doi:10.1016/j.joi.2007.11.001.

[8] Chang $\mathrm{Y}-\mathrm{W}$, Huang $\mathrm{M}-\mathrm{H}$, Lin $\mathrm{C}-\mathrm{W}$. Evolution of research subjects in library and information science based on keyword, bibliographical coupling, and co-citation analyses. Scientometrics 2015;105:2071-87. doi:10.1007/s11192-015-1762-8.

[9] Katibeh M, Moein H-R, Javadi M-A. Contribution of Iran to the Ophthalmic Literature over the Past Three Decades. J Ophthalmic Vis Res 2011;6:225-6.

[10] Sweileh WM, Al-Jabi SW, Shanti YI, Sawalha AF, Sa'ed HZ. Contribution of Arab researchers to ophthalmology: a bibliometric and comparative analysis. SpringerPlus 2015;4:1-7.

[11] Boudry C, Denion E, Mortemousque B, Mouriaux F. Trends and topics in eye disease research in PubMed from 2010 to 2014. PeerJ 2016;4:e1557. doi:10.7717/peerj.1557.

[12] Boudry C, Mouriaux F. Eye neoplasms research: a bibliometric analysis from 1966 to 2012. Eur J Ophthalmol 2015;25:357-65. doi:10.5301/ejo.5000556.

[13] Pekel E, Pekel G. Publication trends in corneal transplantation: a bibliometric analysis. BMC Ophthalmol 2016;16:194. doi:10.1186/s12886-016-0379-x.

[14] Schulz CB, Kennedy A, Rymer BC. Trends in ophthalmology journals: a five-year bibliometric analysis (2009-2013). Int J Ophthalmol 2016;9:1669-75. doi:10.18240/ijo.2016.11.22.

[15] Fu H-Z, Wang M-H, Ho Y-S. Mapping of drinking water research: A bibliometric analysis of research output during 1992-2011. Sci Total Environ 2013;443:757-65. doi:10.1016/j.scitotenv.2012.11.061.

[16] Deshazo JP, Lavallie DL, Wolf FM. Publication trends in the medical informatics literature: 20 years of "Medical Informatics" in MeSH. BMC Med Inform Decis Mak 2009;9:7. doi:10.1186/1472-6947-9-7.

[17] Garfield E. Keywords plus-ISIS breakthrough retrieval method. 1. Expanding your searching power on current-contents on diskette. Current Contents 1990:5-9.

[18] Neri M, Milazzo D, Ugolini D, Milic M, Campolongo A, Pasqualetti P, et al. Worldwide interest in the comet assay: a bibliometric study. Mutagenesis 2015;30:155-63. doi:10.1093/mutage/geu061.

[19] Ramos JM, González-Alcaide G, Bolaños-Pizarro M. Bibliometric analysis of leishmaniasis research in Medline (1945-2010). Parasite Vector 2013;6:55.

[20] Kurmis AP. Understanding the Limitations of the Journal Impact Factor. J Bone Joint Surg Am 2003;85:2449-54.

[21] Michon F, Tummers M. The Dynamic Interest in Topics within the Biomedical Scientific Community. PLoS One 2009;4:e6544. doi:10.1371/journal.pone.0006544.

[22] Fernandez-Cano A, Torralbo M, Vallejo M. Reconsidering Price's model of scientific growth: an overview. Scientometrics 2004;61:301-321. 
[23] Milner MS, Beckman KA, Luchs JI, Allen QB, Awdeh RM, Berdahl J, et al. Dysfunctional tear syndrome: dry eye disease and associated tear film disorders - new strategies for diagnosis and treatment. Curr Opin Ophthalmol 2017;27 Suppl 1:3-47. doi:10.1097/01.icu.0000512373.81749.b7.

[24] Wen P-F, Dong Z-Y, Li B-Z, Jia Y-Q. Bibliometric analysis of literature on cataract research in PubMed (2001-2013). J Cataract Refract Surg 2015;41:1781-3. doi:10.1016/j.jcrs.2015.07.019.

[25] Goffman W, Warren KS. Dispersion of papers among journals based on a mathematical analysis of two diverse medical literatures. Nature 1969;221:1205-7.

[26] Nash-Stewart CE, Kruesi LM, Del Mar CB. Does Bradford's Law of Scattering predict the size of the literature in Cochrane Reviews? J Med Libr Assoc 2012;100:135-8. doi:10.3163/15365050.100.2.013.

[27] Wakeling S, Willett P, Creaser C, Fry J, Pinfield S, Spezi V. Open-Access Mega-Journals: A Bibliometric Profile. PLOS ONE 2016;11:e0165359. doi:10.1371/journal.pone.0165359.

[28] Zhang J, Yu Q, Zheng F, Long C, Lu Z, Duan Z. Comparing keywords plus of WOS and author keywords: A case study of patient adherence research: Comparing Keywords Plus of WOS and Author Keywords. Journal of the Association for Information Science and Technology 2016;67:967-72. doi:10.1002/asi.23437.

[29] Li L-L, Ding G, Feng N, Wang M-H, Ho Y-S. Global stem cell research trend: Bibliometric analysis as a tool for mapping of trends from 1991 to 2006. Scientometrics 2009;80:39-58. doi:10.1007/s11192-008-1939-5.

[30] Yao Q, Chen K, Yao L, Lyu P, Yang T, Luo F, et al. Scientometric trends and knowledge maps of global health systems research. Health Research Policy and Systems 2014;12:26. doi:10.1186/1478-4505-12-26.

[31] Névéol A, Doğan RI, Lu Z. Author keywords in biomedical journal articles. AMIA Annu Symp Proc 2010;2010:537-41.

[32] Ugolini D, Cimmino MA, Casilli C, Mela GS. How the European Union writes about ophthalmology. Scientometrics 2001;52:45-58. doi:10.1023/A:1012746927721.

[33] Medical Subject Headings $\left(\mathrm{MESH}^{\circledR}\right)$ Fact 2015. http://www.nlm.nih.gov/pubs/factsheets/mesh.html (accessed April 4, 2017). 


\section{Figures captions}

Figure 1: Growth of the literature related to DED (annual number and total number of articles)

Figure 2: Network visualization map for country collaboration. A minimum of five documents per country was set as the threshold and 50 countries were included in the map. The thickness of the link between any two countries is indicative of the extent of co-authorship (i.e., collaboration), and the colors of the circles indicate groups of countries with a high degree of collaboration 


\section{Tables}

\begin{tabular}{|l|c|c|}
\hline \multicolumn{1}{|c|}{ Country } & No. of articles (\%) & No. of citations (\%) \\
\hline USA & $1907(34.53)$ & $48053(46.10)$ \\
\hline Japan & $593(10.74)$ & $14736(14.14)$ \\
\hline United Kingdom & $421(7.62)$ & $5368(5.15)$ \\
\hline People's R China & $410(7.42)$ & $10221(9.80)$ \\
\hline Germany & $373(6.75)$ & $6028(5.78)$ \\
\hline Italy & $281(5.09)$ & $4540(4.35)$ \\
\hline Spain & $274(4.96)$ & $5174(4.96)$ \\
\hline Turkey & $248(4.49)$ & $2447(2.35)$ \\
\hline Australia & $232(4.20)$ & $4199(4.03)$ \\
\hline South Korea & $231(4.18)$ & $2043(1.96)$ \\
\hline France & $196(3.55)$ & $3775(3.62)$ \\
\hline Canada & $161(2.92)$ & $3100(2.97)$ \\
\hline Brazil & $147(2.66)$ & $4774(4.58)$ \\
\hline India & $142(2.57)$ & $1305(1.25)$ \\
\hline Singapore & $106(1.92)$ & $1279(1.23)$ \\
\hline Table $1: T o p ~ 15 ~$ & \\
\hline
\end{tabular}

Table 1: Top 15 most productive countries for DED research 


\section{ACCEPTED MANUSCRIPT}

\begin{tabular}{|l|c|c|}
\hline \multicolumn{1}{|c|}{ Institution (country) } & No. of articles (\%) & No. of citations (\%) \\
\hline Harvard University (USA) & $300(5.43)$ & $9577(9.19)$ \\
\hline Keio University (Japan) & $246(4.45)$ & $5604(6.98)$ \\
\hline Baylor College of Medicine (USA) & $148(2.68)$ & $6930(6.65)$ \\
\hline Tokyo Dental College (Japan) & $142(2.57)$ & $2216(2.13)$ \\
\hline University of California System (USA) & $140(2.53)$ & $3910(3.75)$ \\
\hline VA Boston Healthcare System (USA) & $131(2.37)$ & $3238(3.11)$ \\
\hline Massachusetts Eye Ear Infirmary (USA) & $115(2.08)$ & $5698(5.47)$ \\
\hline Allergan Pharmaceuticals Inc. (USA) & $100(1.81)$ & $2129(2.04)$ \\
\hline University of Waterloo (Canada) & $97(1.76)$ & $3889(3.73)$ \\
\hline Ohio State University (USA) & $94(1.70)$ & $3773(3.62)$ \\
\hline University of Miami (USA) & $93(1.68)$ & $1096(1.05)$ \\
\hline University of New South Wales Sydney (Australia) & $87(1.57)$ & $1480(1.42)$ \\
\hline P. \& M. Curie University XV-XX National Eye Center & $83(1.50)$ & $2268(2.18)$ \\
\hline - APHP (France) & $78(1.41)$ & $1968(1.89)$ \\
\hline Johns Hopkins University (USA) & $74(1.34)$ & \\
\hline Kyoto Prefectural University of Medicine (Japan) & & \\
\hline
\end{tabular}

Table 2: Top 15 most productive institutions for DED research 


\begin{tabular}{|c|c|c|c|c|c|c|}
\hline Author & Institution & $\begin{array}{l}\text { Number of } \\
\text { articles (\%) }\end{array}$ & $\begin{array}{l}\text { Number of } \\
\text { citations (\%) }\end{array}$ & $\begin{array}{c}\text { Mean } \\
\text { citations } \\
\text { per article }\end{array}$ & $\begin{array}{l}\text { Number } \\
\text { of years } \\
\text { of activity }\end{array}$ & $\begin{array}{l}\text { Mean number } \\
\text { of articles per } \\
\text { year of activity }\end{array}$ \\
\hline Tsubota K & Keio University, Tokyo, Japan & $266(4.82)$ & $8563(8.22)$ & 32.19 & 15 & 17.73 \\
\hline Pflugfelder SC & Baylor College of Medicine, Houston, TX, USA & $152(2.75)$ & $8235(7.90)$ & 54.18 & 18 & 8.44 \\
\hline Dogru M & Keio University, Tokyo. Tokyo Dental College, Chiba, Japan & $114(2.06)$ & $3342(3.21)$ & 29.32 & 16 & 7.13 \\
\hline Baudouin C & $\begin{array}{l}\text { XV-XX National Eye Center, Paris, France. } \\
\text { Versailles St Quentin en Yvelines University, AP HP, Versailles, } \\
\text { France }\end{array}$ & $90(1.63)$ & $3433(3.29)$ & 38.14 & 21 & 4.29 \\
\hline De Paiva CS & Baylor College of Medicine, Houston, TX, USA & $73(1.32)$ & $2421(2.32)$ & 33.16 & 15 & 4.87 \\
\hline Stern ME & Allergan Pharmaceut Inc., Irvine, CA, USA & $69(1.25)$ & $3736(3.58)$ & 54.14 & 19 & 3.63 \\
\hline Li DQ & Baylor College of Medicine, Houston, TX, USA & $61(1.10)$ & $2609(2.50)$ & 42.77 & 15 & 4.07 \\
\hline Yokoi N & Kyoto Prefectural University of Medicine, Kyoto, Japan & $61(1.10)$ & $1937(1.86)$ & 31.75 & 21 & 2.90 \\
\hline Kinoshita S & Kyoto Prefectural University of Medicine, Kyoto, Japan & $58(1.05)$ & $1909(1.83)$ & 32.91 & 20 & 2.90 \\
\hline Dana $\mathbf{R}$ & Harvard Med School, Boston, MA, USA. & $56(1.01)$ & $1758(1.69)$ & 31.39 & 12 & 4.67 \\
\hline Nichols JJ & University of Alabama, Birmingham, AL, USA & $56(1.01)$ & $1765(1.69)$ & 31.52 & 16 & 3.50 \\
\hline Nichols KK & University of Alabama, Birmingham, AL, USA & $55(0.99)$ & $2470(2.37)$ & 44.91 & 17 & 3.24 \\
\hline Goto $\mathrm{E}$ & Keio University, Tokyo. Tokyo Dental College, Chiba, Japan & $54(0.98)$ & $2270(2.18)$ & 42.04 & 14 & 3.86 \\
\hline Matsumoto $\mathrm{Y}$ & Keio University, Tokyo, Japan & $54(0.98)$ & $1678(1.61)$ & 31.07 & 13 & 4.15 \\
\hline Shimazaki J & Keio University, Tokyo. Tokyo Dental College, Chiba, Japan & $54(0.98)$ & $2755(2.64)$ & 51.02 & 21 & 2.57 \\
\hline
\end{tabular}

Table 3: Top 15 most productive authors in DED research. The institution is the last found in the most recent articles for each author 


\begin{tabular}{|c|c|c|c|c|c|c|c|c|}
\hline \multirow[b]{2}{*}{ Journal } & \multicolumn{5}{|c|}{$1952-2016(n=5522)$} & \multirow{2}{*}{$\begin{array}{l}\begin{array}{c}2008-2010 \\
(n=850)\end{array} \\
\text { No. of } \\
\text { articles (\%) }\end{array}$} & \multirow{2}{*}{ 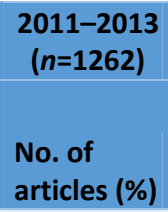 } & \multirow{2}{*}{$\begin{array}{l}\begin{array}{l}2014-2016 \\
(n=1688)\end{array} \\
\text { No. of } \\
\text { articles (\%) }\end{array}$} \\
\hline & $\begin{array}{l}\text { Impact } \\
\text { Factor }^{a} \\
\left.\text { (JCR rank }^{b}\right)\end{array}$ & $\begin{array}{l}\text { No. of } \\
\text { articles (\%) }\end{array}$ & $\begin{array}{l}\text { No. of } \\
\text { citations (\%) }\end{array}$ & $\begin{array}{l}\text { Citations } \\
\text { per } \\
\text { article }\end{array}$ & $\begin{array}{l}\% \text { Of articles } \\
\text { related to DED }\end{array}$ & & & \\
\hline Cornea & $1.833(26)$ & $500(9.05)$ & $10758(10.32)$ & 21.52 & 8.20 & 79 (9.29) & $105(8.32)$ & $136(8.06)$ \\
\hline $\begin{array}{l}\text { Investigative Ophthalmology \& } \\
\text { Visual Science }\end{array}$ & $3.427(6)$ & $477(8.64)$ & $13554(13)$ & 28.42 & 0.50 & $71(8.35)$ & $153(12.12)$ & $144(8.53)$ \\
\hline Optometry and Vision Science & $1.442(37)$ & $222(4.02)$ & $3874(3.72)$ & 17.45 & 4.42 & 45 (5.29) & $51(4.04)$ & $76(4.50)$ \\
\hline American Journal of Ophthalmology & $3.831(5)$ & $159(2.88)$ & $6297(6.04)$ & 39.60 & 0.91 & $20(2.35)$ & $26(2.06)$ & $41(2.43)$ \\
\hline Current Eye Research & $2.025(22)$ & $151(2.73)$ & $2443(2.34)$ & 16.18 & 2.96 & $20(2.35)$ & 40 (3.17) & $54(3.2)$ \\
\hline Ophthalmology & $6.75(2)$ & $147(2.66)$ & $6798(6.52)$ & 46.24 & 0.90 & $20(2.35)$ & $32(2.54)$ & $23(1.36)$ \\
\hline British Journal of Ophthalmology & $3.036(10)$ & $140(2.54)$ & $4050(3.89)$ & 28.93 & 1.02 & 19 (2.23) & 19 (1.51) & $39(2.31)$ \\
\hline Experimental Eye Research & $2.998(13)$ & $135(2.44)$ & $3397(3.26)$ & 25.16 & 1.64 & $20(2.35)$ & $26(2.06)$ & $41(2.43)$ \\
\hline The Ocular Surface & $4.477(3)$ & $131(2.37)$ & $3328(3.19)$ & 25.40 & 31.87 & 25 (2.94) & $26(2.06)$ & $47(2.78)$ \\
\hline $\begin{array}{l}\text { Eye \& Contact Lens-Science and } \\
\text { Clinical Practice }\end{array}$ & $1.252(40)$ & 110 (1.99) & $770(0.74)$ & 7.00 & 15.41 & $31(3.65)$ & $25(1.98)$ & $48(2.84)$ \\
\hline Plos One ${ }^{d}$ & 3.057 & $95(1.72)$ & $695(0.67)$ & 7.32 & 0.06 & $2(0.23)$ & $35(2.77)$ & $56(3.32)$ \\
\hline Contact Lens \& Anterior Eye & $1.752(29)$ & $91(1.65)$ & $607(0.58)$ & 6.67 & 15.56 & $12(1.41)$ & 25 (1.98) & $53(3.14)$ \\
\hline $\begin{array}{l}\text { Journal of Ocular Pharmacology and } \\
\text { Therapeutics }\end{array}$ & $1.754(28)$ & $89(1.61)$ & $993(0.95)$ & 11.16 & 5.17 & 10 (1.18) & $30(2.38)$ & $24(1.42)$ \\
\hline $\begin{array}{l}\text { Graefes Archive for Clinical and } \\
\text { Experimental Ophthalmology }\end{array}$ & $1.991(23)$ & $88(1.59)$ & $1619(1.55)$ & 18.40 & 1.39 & $9(1.06)$ & $22(1.74)$ & $12(0.71)$ \\
\hline JAMA Ophthalmology ${ }^{e}$ & $4.34(4)$ & $76(1.38)$ & $4313(4.14)$ & 56.75 & 0.48 & $17(2)$ & $16(1.27)$ & $9(0.53)$ \\
\hline Molecular Vision & $2.11(20)$ & $70(1.27)$ & $1041(1)$ & 14.87 & 2.15 & $20(2.35)$ & $32(2.54)$ & $16(0.95)$ \\
\hline
\end{tabular}




\begin{tabular}{|c|c|c|c|c|c|c|c|c|}
\hline Eye & $2.213(19)$ & $68(1.23)$ & $1496(1.44)$ & 22.00 & 0.86 & $15(1.76)$ & $10(0.79)$ & $13(0.77)$ \\
\hline $\begin{array}{l}\text { Journal of Cataract and Refractive } \\
\text { Surgery }\end{array}$ & $3.02(12)$ & 65 (1.18) & $1270(1.22)$ & 19.54 & 0.60 & $10(1.18)$ & $9(0.71)$ & $15(0.89)$ \\
\hline $\begin{array}{l}\text { Klinische Monatsblatter Fur } \\
\text { Augenheilkunde }\end{array}$ & $0.689(52)$ & $65(1.18)$ & $265(0.25)$ & 4.08 & 0.51 & $4(0.47)$ & $13(1.03)$ & $11(0.65)$ \\
\hline
\end{tabular}

Table 4: Top 20 most productive journals on DED research

JCR. Journal Citation Report

ampact factor for 2015

${ }^{\mathrm{b}}$ Ranking of journals in the JCR “Ophthalmology” category (2015). This category includes 56 journals

${ }^{c}$ Percentage of articles related to DED relative to the total number of articles published

d JCR category: “Multidisciplinary Sciences” (Rank 11/63)

e Formerly Archives of Ophthalmology

Journal of Ocular Pharmacology and Therapeutics also belongs to the "Pharmacology \& Pharmacy" category (rank 169/255) of the JCR. Molecular Vision also belongs to the "Biochemistry \& Molecular Biology" category (rank 196/289) of the JCR. Journal of Cataract and Refractive Surgery also belongs to the "Surgery" category of the JCR (rank 35/200) 


\begin{tabular}{|l|l|}
\hline KeyWords Plus & $\begin{array}{l}\text { Number of articles } \\
\text { with this keyword } \\
(\%)\end{array}$ \\
\hline Dry Eye & $1457(26.39)$ \\
\hline Ocular Surface & $906(16.41)$ \\
\hline Disease & $770(13.94)$ \\
\hline Keratoconjunctivitis Sicca & $572(10.36)$ \\
\hline
\end{tabular}

\begin{tabular}{ll}
\hline Prevalence & $488(8.84)$ \\
\hline Sjögren's Syndrome & $478(8.66)$ \\
\hline Symptoms & $379(6.86)$ \\
\hline Expression & $366(6.63)$ \\
\hline Dry Eye Disease & $363(6.57)$ \\
\hline Tear Film & $328(5.94)$ \\
\hline
\end{tabular}

\begin{tabular}{ll}
$\begin{array}{l}\text { Meibomian Gland } \\
\text { Dysfunction }\end{array}$ & $261(4.72)$ \\
\hline Risk Factors & $225(4.07)$ \\
\hline Efficacy & $214(3.88)$ \\
\hline Diagnosis & $213(3.86)$ \\
\hline In-Situ Keratomileusis & $212(3.84)$ \\
\hline Cells & $203(3.68)$ \\
\hline Dry Eye Syndrome & $190(3.44)$ \\
\hline Management & $188(3.40)$ \\
\hline Population & $184(3.33)$ \\
\hline Film & $181(3.28)$ \\
\hline
\end{tabular}

Table 5: Top 20 KeyWords Plus for DED research. KeyWords Plus provides additional search terms generated by an automatic computer algorithm, extracted from titles of articles cited by authors in their bibliographies and footnotes 


\section{Supplementary data}

\begin{tabular}{lll|}
\hline $\begin{array}{l}\text { Web of Science categories } \\
\text { Ophthalmology }\end{array}$ & $\begin{array}{l}\text { Number of } \\
\text { articles }\end{array}$ & $\begin{array}{l}\text { Percentage } \\
\text { of articles }\end{array}$ \\
\hline Pharmacology Pharmacy & 312 & 70.48 \\
\hline Surgery & 258 & 4.65 \\
\hline Medicine Research Experimental & 256 & 4.64 \\
\hline Biochemistry Molecular Biology & 186 & 3.37 \\
\hline Medicine General Internal & 149 & 2.7 \\
\hline Immunology & 146 & 2.64 \\
\hline Multidisciplinary Sciences & 136 & 2.46 \\
\hline Cell Biology & 102 & 1.85 \\
\hline Oncology & 80 & 1.45 \\
\hline
\end{tabular}

Top 10 JCR categories of journals on DED research 
The importance of the omega-6/omega-3 fatty acid Simopoulos AP

ratio in cardiovascular disease and other chronic

diseases

The definition and classification of dry eye disease: Lemp MA, Baudouin C, Baum J,

Report of the Definition and Classification Dogru M, Foulks GN et al.

Subcommittee of the international Dry Eye Workhop

(2007)

Reliability and validity of the ocular surface disease

index

Prevalence of dry eye syndrome among US women

Prevalence of and risk factors for dry eye syndrome

Schiffman RM, Christianson MD, Jacobsen G, Hirsch JD, Reis BL

Schaumberg DA, Sullivan $D A$,

Buring JE, Dana MR

Moss SE, Klein R, Klein BEK

Publication

JCR Category

Number of Citations Main subject

year

2008

Journal

Experimental Biology Medicine, Research \&

the article and Medicine

Experimental

2007 Ocular Surface

Ophthalmology

669

66.9

DED

The pathology of dry eye: The interaction between the ocular surface and lacrimal glands

Stern ME, Beuerman RW, Fox RI,

Gao JP, Mircheff AK et al.

Evolutionary aspects of diet, the omega-6/omega-3 Simopoulos AP

ratio and genetic variation: nutritional implications for

chronic diseases

Two multicenter, randomized studies of the efficacy Sall K, Stevenson OD, Mundorf TK, and safety of cyclosporine ophthalmic emulsion in Reis BL

moderate to severe dry eye disease

Prevalence of dry eye among the elderly

\begin{abstract}
Schein OD, Munoz B, Tielsch JM,
\end{abstract}
BandeenRoche K, West S

Pro- and anti-inflammatory forms of interleukin-1 in the Solomon A, Dursun D, Liu ZG, Xie 200

tear fluid and conjunctiva of patients with dry-eye $\mathrm{YH}$, Macri A et al.

disease

Altered cytokine balance in the tear fluid and Pflugfelder SC, Jones D, Ji ZH, 1999 Current Eye Researc

conjunctiva of patients with Sjogren's syndrome Afonso A, Monroy

keratoconjunctivitis sicca

Pharmacological profiles of cloned mammalian P2Y- von Kugelgen I

receptor subtypes

Surgical reconstruction of the ocular surface in Tsubota K, Satake Y, Ohyama M, 1996

advanced ocular cicatricial pemphigoid and Stevens- Toda I, Takano Y et al.

2000

Archives of

Ophthalmology

Ophthalmology

American Journal of

Ophthalmology

668

39.29

Ophthalmology

465

33.22

Ophthalmology

Ophthalmology

Ophthalmology

Cornea

Ophthalmology

$428 \quad 25.18$

Biomedici

Pharmacotherapy.

Medicine, Research \&

Experimental

Pharmacology \& Pharmacy

Ophthalmology

$416 \quad 21.89$

DED

DED

Ophthalmology

Ophthalmology

387

35.18

Other

2000

cy

$369 \quad 21.71 \quad$ DED

American Journal of

Ophthalmology

368

18.4

DED

Ophthalmology

Ophthalmology

349

21.81

DED

nvestigative

Ophthalmology

343

19.05

DED

Pharmacology $\&$

Pharmacology \& Pharmacy

Therapeutics

American Journal of

Ophthalmology

332

30.18

Other

Ophthalmology

328

15.62

Other 
Bron AJ, Tiffany JM, Gouveia SM,

2004
Yokoi N, Voon LW

Treatment of severe ocular-surface disorders with Tsubota K, Satake $\mathrm{Y}$, Kaido $\mathrm{M}$,

Shinozaki N, Shimmura $S$ et al.

corneal epithelial stem-cell transplantation

Chitosan nanoparticles: a new vehicle for the De Campos AM, Sanchez A, Alonso MJ

surface. Application to cyclosporin A

Grading of corneal and conjunctival staining in the Bron AJ, Evans VE, Smith JA

context of other dry eye tests

Experimental dry eye stimulates production of Luo LH, Li DQ, Doshi A, Farley W, 2004

inflammatory cytokines and MMP-9 and activates Corrales RM et al.

MAPK signaling pathways on the ocular surface

The lack of association between signs and symptoms in Nichols KK, Nichols JJ, Mitchell GL

Experimental Eye

Ophthalmology

Research

New England Journa

of Medicine

Medicine, General \&

Internal

2001 International Journal Pharmacology \& Pharmacy

of Pharmaceutics

Cornea

Ophthalmology

279

Ophthalmology

279

Investigative

Ophthalmology \&

Visual Science

patients with dry eye disease

Cornea

Ophthalmology

272 


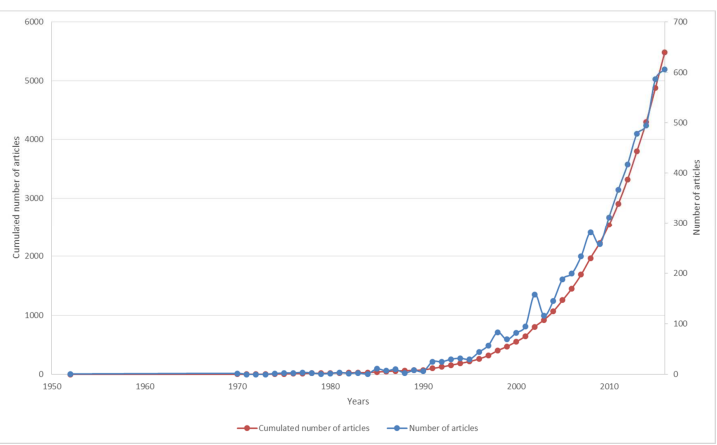




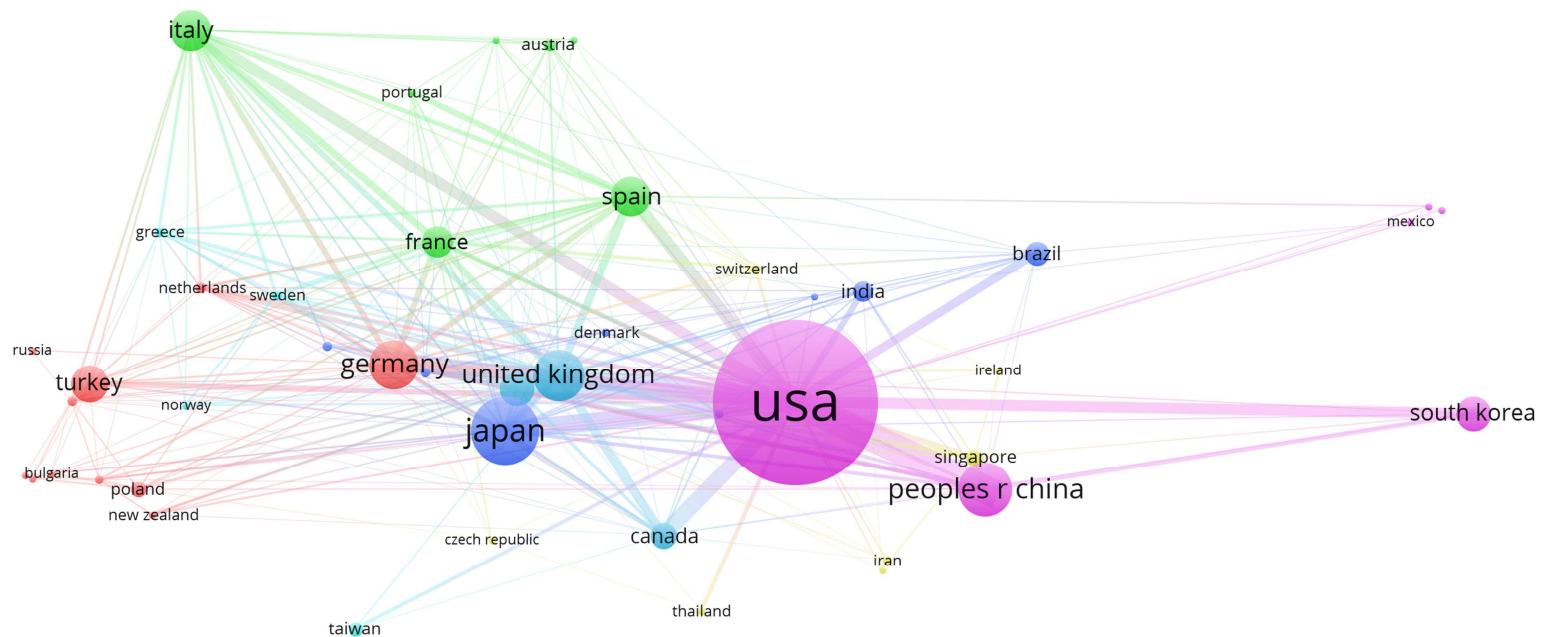

taiwan 